ISSN 0103-5150

Fisioter. Mov., Curitiba, v. 29, n. 3, p. 527-531, Jul./Set. 2016

Licenciado sob uma Licença Creative Commons

DOI: http://dx.doi.org.10.1590/1980-5918.029.003.A010

\title{
Correlation between temporomandibular disorder and quality of sleep in women
}

\section{Correlação entre Disfunção temporomandibular e qualidade do sono em mulheres}

\author{
Juliana de Paiva Tosato ${ }^{[a, b]}$, Fabiano Politti ${ }^{[b]}$, Marilia Barbosa Santos Garcia ${ }^{[b]}$, \\ Tabajara de Oliveira Gonzalez ${ }^{[\mathrm{b}]}$, Daniela Aparecida Biasotto-Gonzalez ${ }^{[\mathrm{b}]^{*}}$ \\ [a] Universidade Estadual de Campinas (UNICAMP), Campinas, SP, Brazil \\ [b] Universidade Nove de Julho (UNINOVE), São Paulo, SP, Brazil
}

\begin{abstract}
Introduction: Temporomandibular Disorder (TMD) is caused by multiple factors and exhibits various symptoms. Its most common symptom is pain, a factor that can influence the quality of an individual's sleep. Objective: The aim of the present study was to assess the correlation between TMD and sleep. Methods: A cross-sectional study was conducted with 60 women, aged between 18 and 40 years, who had been diagnosed with TMD based on the Research Diagnostic Criteria for Temporomandibular Disorders (RDC/TMD). Fonseca's anamnestic index (FAI) was used to classify the severity of the dysfunction. To complete the assessment, each volunteer was assessed using the visual analogue scale (VAS) for pain. They also responded to two questions related to their quality of sleep and the average hours of sleep per night. Results: The more severe the TMD, the fewer hours of sleep per night ( $r=-0.5663$ ). In total, 63.33\% of the volunteers reported not sleeping well. Concerning pain, the greater the VAS score, the less hours
\end{abstract}

\footnotetext{
*JPT: PhD, e-mail: jptfisioterapia@ig.com.br FP: PhD, e-mail: politti@uninove.br MBSG: Doctoral Student, e-mail: mariliabsg@gmail.com TOG: PhD, e-mail: togonzalez@uninove.br DABG: PhD, e-mail: dani_atm@uninove.br
} 
of sleep ( $r=-0.516)$ and the more severe the TMD. Conclusion: It was found that the severityof TMD was correlated with pain symptoms and the number of hours of sleep per night.

Keywords: Temporomandibular Joint Disorder. Pain. Sleep.

\section{Resumo}

Introdução: A etiologia da Disfunção Temporomandibular (TMD) é multifatorial e apresenta sintomatologia variada, sendo a dor o sintoma mais comum, o que pode influenciar na qualidade do sono. Objetivo: Este estudo teve como objetivo avaliar a correlação entre a TMD e a qualidade e quantidade de sono. Métodos: Estudo transversal no qual foram selecionadas 60 mulheres entre 18 e 40 anos, portadoras de TMD, diagnosticadas por meio do Critérios de Diagnóstico para Pesquisa das Desordens Temporomandibulares (RDC/TMD), e que responderam ao Índice Anamnético de Fonsecapara classificação quanto ao grau de severidade da disfunção. Para completar a avaliação, cada voluntária respondeu a Escala visual analógica da dor, e duas questões com relação a qualidade do sono, e a quantidade média de horas de sono por noite. Resultados: Verificou-se que quanto mais severa a TMD, menor o número de horas dormidas por noite ( $r=-0,5663)$ e 63,33\% das voluntárias relataram não dormir bem. Com relação a dor, quanto maior a dor, menor as horas dormidas $(r=-0,516)$ e quanto mais severa a TMD, maior a dor. Conclusão: Observou-se que quanto mais severa a TMD, maior a dor e menor o número de horas que as voluntárias referiam dormir por noite.

Palavras-chave: Transtornos da Articulação Temporomandibular. Dor. Sono.

\section{Introduction}

Temporomandibular disorder (TMD) can be defined as a disorder that involves the muscles of mastication, the temporomandibular joint (TMJ) and associated structures $(1,2)$. Its etiology is multi-factorial and involves different aspect, including muscle problems, occlusal issues, structural and postural abnormalities, psychological problems, parafunctional habits, degenerative processes and traumatic injuries (3).

Despite this characterization of varied symptomatology, pain is the most commonly observed symptom $(4,5,6,7)$. Although both men and women are affected by TMD, the disorder is more common among women(8). Chronic pain can lead to physical, psychological and social effects, with a direct impact on the individual's quality of life $(9,10,11)$. Sleep can be affected by the constant presence of nociceptive stimuli $(12,13)$.

Oliveira et al. (14) assessed volunteers with TMD and confirmed that the quality of sleep was endangered in more than $50 \%$ of the participants. The same authors stated that a higher intensity of pain was correlated with a lower quality of sleep. Similar results were found by Verri et al. (15), who assessed 101 university students. Among those assessed, more severe TMD was correlated with a worse quality of sleep.
Sleep is fundamentally important for the body, helping it to recuperate and preserving the individuals physical, mental and psychological health (16). Abnormalities that can negatively affect sleep should be assessed and controlled. Thus, the aim of the present study was to assess the correlation between temporomandibular disorder and the quality and quantity of sleep among women.

\section{Methods}

Study Design

This is a cross-sectional study, which assessed the correlation between TMD and the quality and quantity of nocturnal sleep. This study is in accordance with Resolution 196/96 of the National Health Council (M/S, 10/10/96) and received approval from the Research Ethics Committee of the institution in question, under protocol number 245845 .

\section{Volunteers}

Ninety-three volunteers from the physiotherapy clinic of the UniversidadeNove de Julhowere first interviewed. All 93 expressed an interest in participating. 
However, 33 of them were excluded for not satisfying the inclusion criteria. Sixty volunteers, aged between 18 and 40 years, who had been diagnosed with TMD through the Research Diagnostic Criteria for Temporomandibular Disorders(RDC/TMD) (17), were selected to participate in this research. They had no dental flaws, a class I angle and werenot undergoing any dental treatment or taking medication (analgesic, anti-inflammatory or muscle relaxant). They also had no medical history of systemic disease or facial trauma and were not oral breathers.

\section{Procedures}

The volunteers were first submitted to the RDC/ TMD(17), an instrument that enables a diagnosis of TMD to be made using a translated and validated questionnaire. Subsequently, they completed the Fonseca anamnestic index (18), which contains 10 questions and three answer options: yes (10 points); no ( 0 points) and sometimes ( 5 points). These answers provide a score and classify TMD in terms of severity. To complete the assessment, each volunteer was tested using the visual analog scale (VAS) and responded to two questions related to their sleep patterns: did they think they slept well (yes or no answer); and how many hours did they sleep per night (average).

\section{Data Analysis}

After finishing the data collection, Spearman's correlation was applied to determine if there was a correlation between the severity of TMD, pain and hours of sleep. The following correlation values wereconsidered: $r=0$, zero correlation; $r$ between 0 and 0.3 , weak correlation; $r$ between 0.31 and 0.6 , regular correlation; $r$ between 0.61 and 0.9 , strong correlation; $r$ between 0.91 and 0.99 , very strong correlation and $r$ $=1$, full correlation. Version 5.3 of BioEstatwas used to analyze and process the data (Belém, PA, Brazil).

\section{Results}

All of the volunteers assessed exhibited TMD according to the RDC/TMD, with painful symptoms for at least three months and a VAS score of at least three points. After the diagnosis of the disorder, Fonseca's anamnestic index (18) was used to classify the disorder as mild, moderate or severe.
Once the number of hours the participants slept per night had been established, tests were run to determine if there was a negative correlation with the severity of the disorder $(r=-0.5663)$. Concerning the quality of sleep, when questioned, $63.33 \%$ of the volunteers claimed not to sleep well. Upon correlation of the pain scale and the hours of sleep, it was found that greater pain led to less hours of sleep ( $\mathrm{r}$ $=-0,516)$. Upon correlating the severity of TMD with the pain scale, it was clear that pain increases in line with the severity of TMD $(r=0.75)$. Thus, it is possible to suggest that more severe TMD leads to greater pain and less hours of sleep per night.

Table 1 - Correlation between the severity of TMD, pain and hours of sleep

\begin{tabular}{lc}
\hline & Correlation \\
\hline Hours of sleep $x$ TMD & $-0.566^{\star}$ \\
\hline VAS pain $x$ Hours of sleep & $-0.516^{\star}$ \\
\hline TMD x VAS pain & $0.750^{\star}$ \\
\hline
\end{tabular}

Note: ${ }^{*} p<0.05$

\section{Discussion}

In order to select the volunteers, two instruments were used. The RDC/TMD and the Fonseca anamnestic index enable a diagnosis of TMD and a classification of the severity of the disorder, respectively. Both of these instruments are established in the literature $(17,18,19,20,21,22,23)$. The VAS was used to assess pain as it is reproducible and easy to understand (24). Concerning sleep, two simple questions were selected that would enable correlations to be analyzed between this variable and the pathology in question (TMD). This approach was used considering the hypothesis that there could be a correlation between pain, typical among patients with TMD, and sleeping problems, given that pain is a potential cause of insomnia, due to the fact that it can cause discomfort and changes in the individuals regulation system.

Brosseau et al. (25) explained that there is a correlation between sleep problems and pain, suggesting that this abnormality is based on the neuro-endocrine system, which regulates both entities. Disorders of the pituitary-adrenal axis and the limbic system are intimately connected to sleep, a factor that predisposes patients with chronic pain to a greater risk of insomnia (1). Abdala and Bahammam (26) stated 
that sleep deprivation could be correlated with neurohormonal changes. Valenza et al. (27) reported that sleep is an important restorative agent for the body and sleep deprivation can lead to physiological and neurological problems, increasing the heart rate, blood pressure, activity of the sympathetic nervous system and levels of cortisol (the hormone related to stress), while also causing hyperglycemia and fatigue. The authors also reported that between 50 and $80 \%$ of patients with chronic pain suffer from sleep disorders.

Sleep is an important restorative function for the body. Dattilo et al. (28) reported that poor quality sleep decreases protein synthesis and increases degradation processes, leading to abnormalities in the metabolism of the muscles. It has been suggested that this can affect the patterns of muscle activation in TMD patients, leading to tension-related headaches. Oliveira et al. (29) stated that TMD has a negative effect on the quality of sleep and quality of life. Lei et al. (30) investigated the prevalence of sleep disorders among TMD patients and confirmed that the two variables were correlated, given that the frequency of sleep disorders was significantly higher among those with TMD, when compared with healthy individuals.

Based on the results of the present study, and considering that a correlation was found between the severity of TMD, pain and sleep, further studies should be conducted with a more complex approach, highlighting the multi-factorial nature of this disease. It isalso worth stressing that improving the quality of the individual's sleep should be considered as a therapeutic strategy for these patients.

In the present study, the authors opted to use simple questions to assess sleep as these questions could be easily replicated in clinical practice. However, more complex questionnaires and supplementary examinations would be extremely valuable in the assessment of sleep (quality and quantity) in future studies.

\section{Conclusion}

It is clear that more severe cases of TMD are characterized by greater levels of pain and less hours of sleep per night. Therefore, it is suggested that assessmentsof the quality and quantity of sleep are considered for patients with this disorder, and other pathologies involving pain.

\section{Acknowledgements}

The authors would like to thank CAPES for their financial support.

\section{References}

1. Carrara SV, Conti PCR, Barbosa JS. Termo do 1ํㅡㄴ senso em Disfunção Temporomandibular e Dor Orofacial. Dental Press J Orthod. 2010;15(3):114-20.

2. Leeuw R. Orofacial pain: guidelines for assessment, diagnosis, and management. 4th ed. Chicago: Quintessence; 2008.

3. Pereira Jr FJ, Vieira AR, Prado R, Miasato JM.Visão geral das disfunções temporomandibulares. RGO Rev Gaúcha Odontol.2004;52(2):117-21.

4. Truelove EL, Sommers EE, LeResche L, Dworkin SF, Von Korff M.Clinical diagnostic criteria for TMD. New classification permits multiple diagnoses. J Am Dent Assoc. 1992;123(4):47-54.

5. Plesh O, Sinisi SE, Crawford PB, Gansky SA.Diagnoses based on the Research Diagnostic Criteria for Temporomandibular Disorders in a biracial population of young women. JOrofac Pain. 2005;19(1):65-75.

6. Orlando B,Manfredini D, Bosco M. Efficacy of physical therapy in the treatment of masticatory myofascial pain: a literature review. Minerva Stomatol. 2006;55(6):355-66.

7. Gonçalves DA, Dal Fabbro AL, Campos JA, Bigal ME, Speciali JG.Symptoms of temporomandibular disorders in the population: an epidemiological study. JOrofacPain. 2010;24(3):270-8.

8. Zanettini I, Zanettini UM. Disfunções temporomandibulares: estudo retrospectivo de 150 pacientes. Rev Cient AMECS. 1999;8(1):9-15.

9. Brown FF, Robinson ME, Riley JL, Gremillion HA. Pain severity, negative effects, and microstressers as predisctors of life intereference in TMD patients. Cranio. 1996;14(1):63-70.

10. Moreno BGD, Maluf SA, MarquesAP, Crivello-Júnior O. Clinical and quality-of-life assessment among women with temporomandibular disorder. Rev Bras Fisioter. 2009;13(3):210-4. 
11. Karacayli U, Mumcu G, Cimilli H, Sisman N, Sur H, Gunaydin Y.The effects of chronic pain on oral health related quality of life in patients with anterior disc displacement with reduction. Community Dent Health. 2011;28(3):211-5.

12. Yatani H, Studts J, Cordova M, Carlson CR, Okeson JP.Comparison of sleep quality and clinical and psychologic characteristics in patients with temporomandibular disorders. JOrofac Pain. 2002;16(3):221-8.

13. Smith MT, Wickwire EM, Grace EG, Edwards RR, Buenaver LF, Peterson S, et al. Sleep disorders and their association with laboratory pain sensitivity in temporomandibular joint disorder. Sleep. 2009;32(6):779-90.

14. Oliveira AS, Bermudez CC, Souza RA, Souza CMF, Dias EM, CastroCE, et al. Impacto da dor na vida de portadores de Disfunção Temporomandibular. J Appl Oral Sci. 2003;11(2):138-43.

15. Verri FR, Garcia AR, Zuim PRJ, AlmeidaEO, FalconAntenucci RM, Shibayama R. Avaliação da qualidade do sono em grupos com diferentes níveis de desordem temporomandibular.Pesqui. BrasOdontopediatriaClin Integr. 2008;8(2):165-9.

16. Silva SR. Como ajudar o paciente roncador. RevAssoc Paul CirDent. 2002;56(4):247-57.

17. Dworkin SF, Le Resche L. Research diagnostic criteria for temporomandibular disorders: review, criteria, examinations and specifications critique. J CraniomandibDisord. 1992;6(4):301-55.

18. Fonseca DM. Diagnóstico pela anamnese da disfunção craniomandibular. RGO - Rev Gaúcha Odontol. 1994;42(1):23-8.

19. LookJO, Schiffman EL, TrueloveEL, Ahmad M.Reliability and validity of Axis I of the Research Diagnostic Criteria for Temporomandibular Disorders (RDC/TMD) with proposed revisions. J Oral Rehabil. 2010;37(10):744-59.

20. Pedroni CR, OliveiraAS, GuaratiniMI. Prevalence study of signs and symptoms of temporomandibular disorders in university students. J Oral Rehabil. 2003;30:283-9.

21. Chaves TC, OliveiraAS, Grossi DB. Principais instrumentos para avaliação da disfunção temporomandibular, parte I: índices e questionários; uma contribuição para a prática clínica e de pesquisa. FisioterPesqui. 2008;15(1):92-100.
22. Gomes CA, Dibai-Filho AV, Silva JR, Oliveira PM, Politti F, Biasotto-Gonzalez DA.Correlation between severity of temporomandibular disorder and mandibular range of motion. J BodywMovTher. 2014;18(2):306-10.

23. Gomes CA, Politti F, Andrade DV, Sousa DF, Herpich CM, Dibai-Filho AV,et al. Effects of massage therapy and occlusal splint therapy on mandibular range of motion in individuals with temporomandibular disorder: a randomized clinical trial. J Manipulative PhysiolTher. 2014;37(3):164-9.

24. Ferreira-Valente MA, Pais-RibeiroJL, Jensen MP. Validity of four pain intensity rating scales. Pain. 2011;152(10): 2399-404.

25. Brousseau M, Manzini C, Thie N, Lavigne G. Understanding and managing the interaction between sleep and pain: an update for the dentist. J Can Dent Assoc. 2003;69(7):437-42.

26. Aldabal L, Bahammam AS. Metabolic, Endocrine, and Immune Consequences of Sleep Deprivation. Open Respir Med J. 2011;5:31-43.

27. Valenza MC, Rodenstein DO, Fernández-de-Las-Penas C. Consideration of sleep dysfunction in rehabilitation. J BodywMovTher. 2011;15(3):262-7.

28. Dattilo M, Antunes HK, MedeirosA, Mônico Neto M, Souza HS, Tufik S, et al.Sleep and muscle recovery: Endocrinological and molecular basis for a new and promising hypothesis. Med Hypotheses. 2011;77(2):220-2.

29. Oliveira JK, AlmeidaGA, Lelis ÉR, Tavares M, Fernades NAJ. Temporomandibular disorder and anxiety, quality of sleep, and quality of life in nursing professionals. Braz Oral Res. 2015;29(1).

30. Lei J, Liu MQ, Yap AU, Fu KY. Sleep disturbance and psychologic distress: prevalence and risk indicators for temporomandibular disorders in a Chinese population. J Oral Facial Pain Headache. 2015;29(1):24-30.

Received in $07 / 20 / 2014$ Recebido em 20/07/2014

Approved in 10/16/2015 Aprovado em 16/10/2015 
